\title{
EFEKTIFITAS USABILITY (PENGGUNAAN) SIGN SYSTEM TEMPAT WISATA KOTA SAWAHLUNTO SEBAGAI KOTA TAMBANG BERBUDAYA
}

\author{
Dwi Mutia Sari ${ }^{*}$, Eko Purnomo ${ }^{2 *}$ \\ Program Studi Desain Komunikasi Visual Jurusan Seni Rupa Fakultas Bahasa dan Seni \\ Universitas Negeri Padang \\ Jl. Prof. Dr. Hamka, Air Tawar Padang, Kel. Air Tawar Barat, Kec. Padang Utara, Kota Padang, Kode Pos 25137 \\ Sumatera Barat. Indonesia \\ Email: mutia2011@fbs.unp.ac.id, ekopurnomoar@gmail.com
}

\begin{abstract}
Abstrak
Kota Sawahlunto merupakan kota wisata dengan menonjolkan dua potensi wisata yang menjadi kekuatannya, Wisata Tambang dan Wisata Sejarah Kota Lama, yang memanfaatkan bekas tambang serta peninggalan bangunan Belanda yang banyak di Kota Sawahlunto. Untuk mendukung wisata di Kota Sawahlunto dikenal luas oleh pengunjung, diperlukan media informasi yang komunikatif agar pengunjung mengetahui identitas suatu objek, informasi serta arah dan lokasi yang akan dituju berikutnya, salah satunya dengan penggunaan media sign system. Penelitian ini bertujuan untuk mengkaji seberapa efektifnya penggunaan sign system tersebut yang sudah diterapkan pada area wisata di sekitar kawasan Kota Sawahlunto dengan menggunakan Direct Rating Method (DRM), melalui pendekatan metode penelitian kuantitatif. Adapun sub variabel yang digunakan adalah perhatian (attention), pemahaman (readthrougness), efek kognitif, efek afektif, dan efek sikap terhadap media (behavioral). Hasil dari penelitian yang melalui olahan 97 responden adalah nilai total dimensi $\mathrm{G}$ atau skor total keseluruhan sub variabel, yaitu sebesar 76,96. Yang selanjutnya nilai tersebut dikonversikan melalui tabel DRM, sehingga sign system termasuk dalam kategori baik sebagai media komunikasi visual yang berada di ruang publik, yaitu berada di wisata Kota Sawahlunto.
\end{abstract}

Kata Kunci: kota sawahlunto, efektif, sign system.

\begin{abstract}
Sawahlunto City is a tourist city by highlighting two tourism potentials that become its strengths, Mining Tourism and Old Town History Tour, which utilizes former mines and the many Dutch heritage buildings in Sawahlunto City. To support tourism in Sawahlunto City, which is widely known by visitors, communicative information media is needed so that visitors know the identity of an object, information as well as the direction and next location, one of which is the use of a sign system as media. This study aims to examine how effective the use of the sign system has been in tourist areas around the City of Sawahlunto using the Direct Rating Method (DRM), through quantitative research methods. The subvariables used are attention, readthrough, cognitive effects, affective effects, and behavioral. The result of the research that was processed by 97 respondents was the total value of the G dimension or the total score of the sub-variables, which was 76.96. The next value is converted through the DRM table, so that the sign system is included in the good category as a visual communication media in public spaces, namely in Sawahlunto City tourism.
\end{abstract}

Keywords: sawahlunto city, effective, sign system.

\section{PENDAHULUAN}

Secara geografis Kota Sawahlunto terletak di $95 \mathrm{~km}$ sebelah timur laut Kota Padang, Provinsi Sumatera Barat dan dikelilingi oleh 3 kabupaten yaitu Kabupaten Tanah Datar, Kabupaten Solok dan Kabupaten Sijunjung. Kota Sawahlunto didirikan pada tahun 1888, saat ini banyak berdiri bangunan tua peninggalan Belanda yang pada masa Pemerintahan Hindia Belanda, Kota Sawahlunto dikenal sebagai kota tambang batu bara. Selain itu, Kota Sawahlunto menjadi tujuan banyak wisatawan, baik wisatawan dari wilayah Sumatera Barat ataupun dari luar wilayah Sumatera Barat, untuk berlibur atau menikmati pariwisata yang ada di daerah Kota Sawahlunto.

Sehubungan dengan hal tersebut, dalam rangka mendorong kepariwisataan Kota Sawahlunto, pemerintah setempat melalui Dinas Kebudayaan Peninggalan Bersejarah Kota Sawahlunto telah menetapkan beberapa hal penting, diantaranya adalah dengan cara tetap mempertahankan keutuhan dan keaslian bangunan peninggalan bersejarah dan 


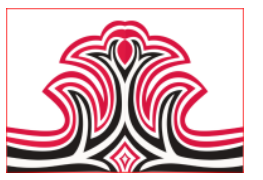

ditetapkan sebagai bangunan cagar budaya, menguatkan mengembangkan pariwisata yang sejalan dengan identitas Kota Sawahlunto, seperti wisata Museum Tambang Ombilin, Kawasan Tambang Batu Bara Ombilin, Lubang Kalam, Gereja Santa Barbara, Puncak Cemara, Puncak Poland, Danau Biru, Batu Runciang, Museum Kereta Api, Makam Belanda, Lubang Mbah Soero, dan lain lain (gambar 1).

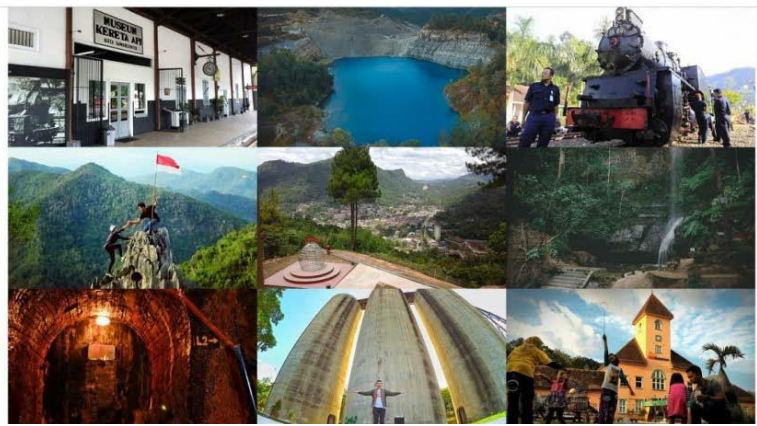

Gambar 1. Foto Bangunan Cagar Budaya Kota Sawahlunto pada Website

(Evrinaldi, 2020)

Berdasarkan dari uraian diatas, terlihat bahwa Kota Sawahlunto merupakan kota wisata yang menonjolkan dua potensi wisata yang menjadi kekuatannya, Wisata Tambang dan Wisata Sejarah Kota Lama. Dengan memanfaatkan bekas tambang serta peninggalan bangunan Belanda yang banyak di Kota Sawahlunto menjadikan Kota Sawahlunto menjadi kota yang unik. Untuk itu, pemerintah setempat bersinergi melalui strategi kreatif city branding membentuk citra Kota Sawahlunto sebagai kota cagar budaya berbasis heritage (Evrinaldi, 2020). Oleh karena hal tersebut, segenap jajaran Pemerintah Kota dan DPRD bersama stake holder kota lain merumuskan Visi Kota Sawahlunto yang dituangkan dalam Peraturan Derah Kota Sawahlunto Nomor 2 Tahun 2001 yaitu "Kota Sawahlunto Tahun 2020 menjadi Kota Wisata Tambang Yang Berbudaya” (Evrinaldi, 2020).

Banyaknya pengunjung yang mengunjungi Kota Sawahlunto tentu membuat perlu adanya sarana untuk mempermudah wisatawan dalam memperoleh informasi ketika berada di lokasi atau petunjuk untuk mengunjungi lokasi lainnya. Salah satu dari sarana yang digunakan Pemerintah Kota Sawahlunto dalam berkomunikasi dengan pengunjung adalah dengan seperangkat sign system.

Sign system merupakan media yang digunakan untuk berinteraksi antar manusia yang berada di lingkungan publik (Rama, 20212). Sign system terdiri dari beberapa macam, yaitu sign system yang berupa petunjuk (Gambar 2), sign system yang berupa larangan (Gambar
Gorga : Jurnal Seni Rupa

Volume 10 Nomor 02 Juli-Desember 2021 p-ISSN: 2301-5942 | e-ISSN: 2580-2380

3). Selain kedua jenis tersebut, juga ada sign system yang berupa pengenal (Gambar 4), dan juga berupa petunjuk arah (Gambar 5). Sign system tersebut merupakan bagian dari media informasi yang berada di lingkungan wisata Kota Sawahlunto.

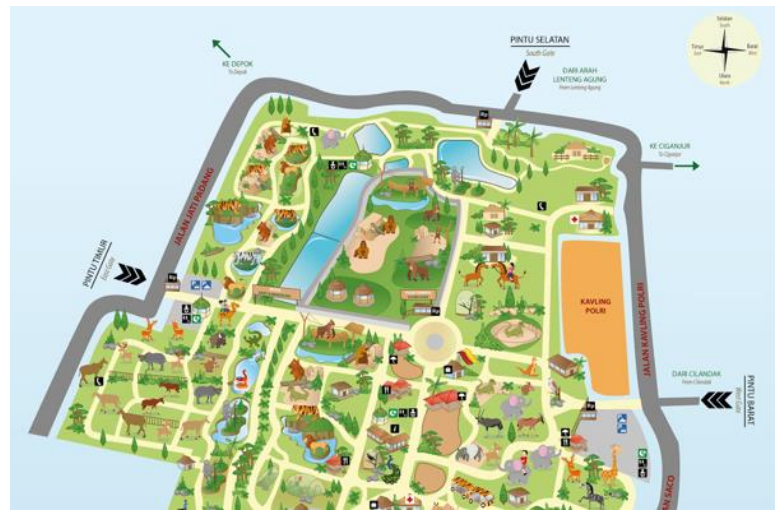

Gambar 2. Contoh Sign System Berupa Petunjuk (Behance, 2020)

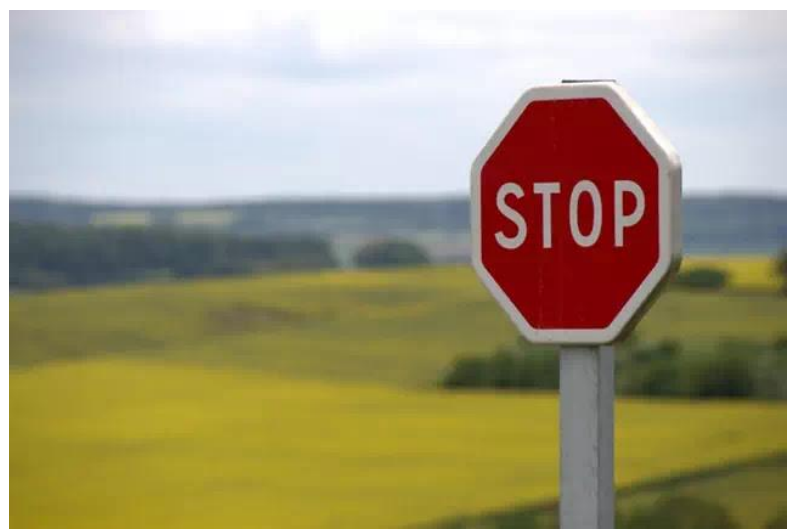

Gambar 3. Contoh Sign System Berupa Larangan (Portaldekave, 2021)

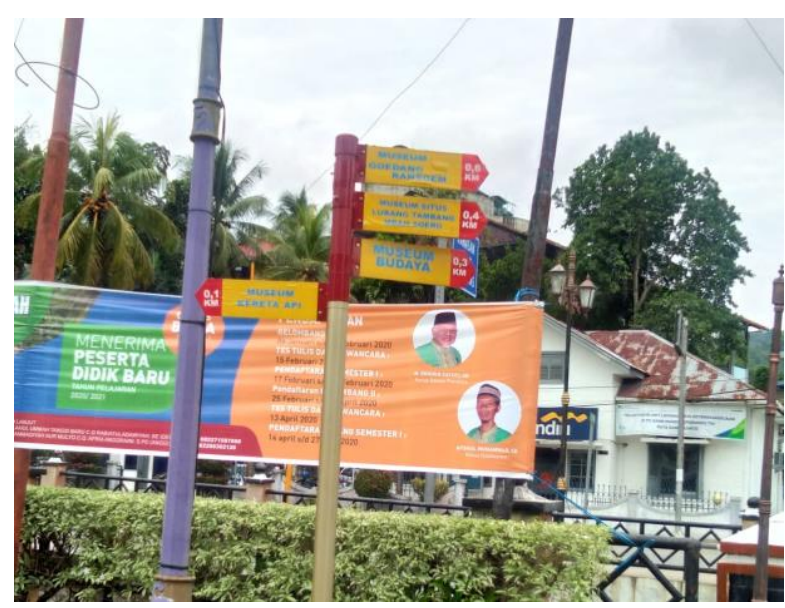

Gambar 4. Sign System Tempat Wisata di Kota Sawahlunto. (Yulnita, 2020) 


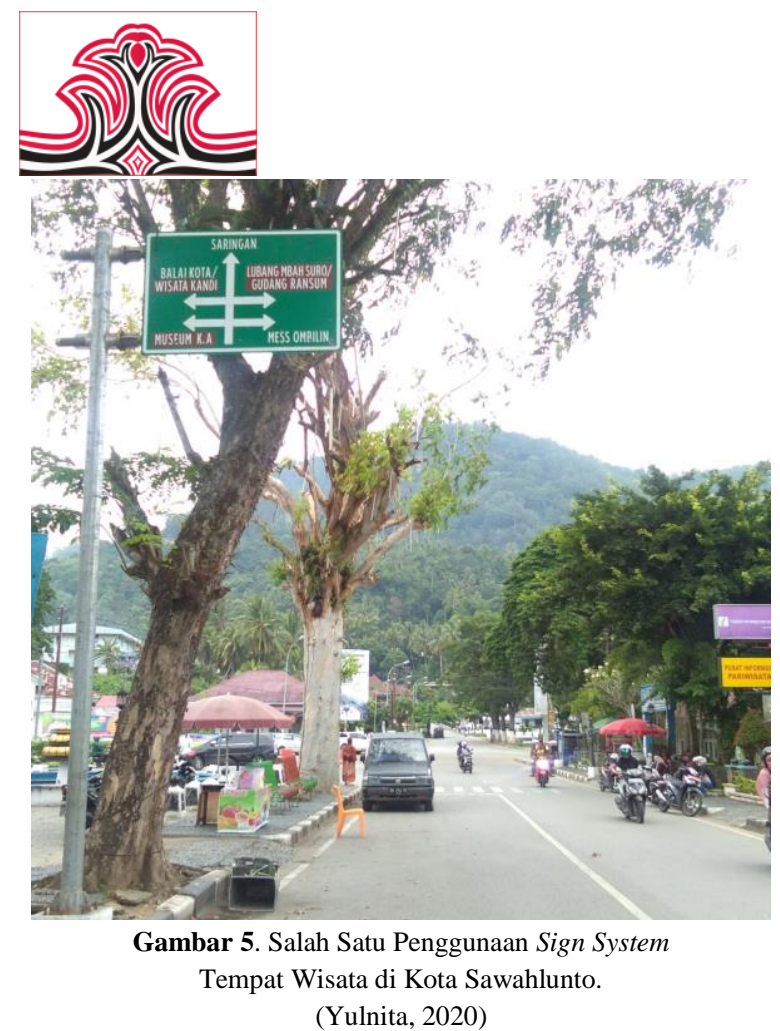

Banyaknya sign system yang berada di wisata Kota Sawahlunto menandakan bahwa sebuah media yang mengkomunikasikan informasi ternyata memiliki peran penting ketika berada di lingkungan publik. Sedemikian pentingnya informasi sehingga memegang peranan yang penting bagi seseorang, maka tentunya media yang mengkomunikasikan informasi tersebut juga patut diperhatikan. Mewujudkan visi Kota Sawahlunto dalam hal media komunikasi yang dapat mempermudah pengunjung dalam memperoleh informasi ketika berada dalam lingkungan wisata serta penunjuk arah dan lokasi wisata dalam bentuk pemasangan sign system, yang sejalan dengan salah satu misinya, yaitu mengembangkan objek wisata tambang dan mengembangkan seluruh potensi kota yang dapat mendorong berkembangnya pariwisata.

Sebagai media komunikasi di wisata Kota Sawahlunto, peneliti kali ini ingin mengukur sejauh mana efektivitas dari penggunaan sign system dalam membantu para pengunjung selama berada di wisata Kota Sawahlunto. Pengukuran efektivitas menggunakan Direct Rating Method (DRM), dengan variabel yang akan diteliti adalah dari aspek perhatian (attention), aspek mudah dibaca (read-throughness), aspek pesan dan manfaat kontrolnya (cognitive), aspek menggugah perasaan (affective), dan aspek sikap (behavior). Penelitian ini mengambil judul "Efektifitas Usability Sign System Tempat Wisata Kota Sawahlunto Sebagai Kota Wisata Tambang Berbudaya".
Gorga : Jurnal Seni Rupa

Volume 10 Nomor 02 Juli-Desember 2021 p-ISSN: 2301-5942 | e-ISSN: 2580-2380

\section{KAJIAN TEORI}

\section{Kota Sawahlunto}

ini Kota Sawahlunto berkembang menjadi kota wisata tua yang multi etnik, bangunan peninggalan Belanda yang masih terjaga kelestariannya yang ditetapkan sebagai cagar budaya oleh pemerintah setempat, serta tempat wisata yang hampir tersebar di seluruh kawasan Kota Sawahlunto, sehingga menjadikan Kota Sawahlunto sebagai salah satu kota tua terbaik di Indonesia (Narny, 2015).

\section{Komunikasi Visual}

Komunikasi visual adalah komunikasi yang menggunakan bahasa visual, di mana unsur dasar bahasa visual (yang menjadi kekuatan utama dalam penyampaian pesan) adalah segala sesuatu yang dapat dilihat dan dapat dipakai untuk menyampaikan arti, makna, atau pesan (Kusrianto, 2009).

Jika dilihat lebih dalam lagi, komunikasi visual selain berakar dari ilmu komunikasi tetapi juga memiliki akar dari bidang seni rupa. Dari beragam cabang-cabangnya, periklanan sendiri berada di bawah naungan desain komunikasi karena memerlukan perancangan visual dalam proses komunikasinya. Hal itu serupa dengan sign system, hal ini membuat posisi periklanan dan sign system sejajar (Bagan 1).

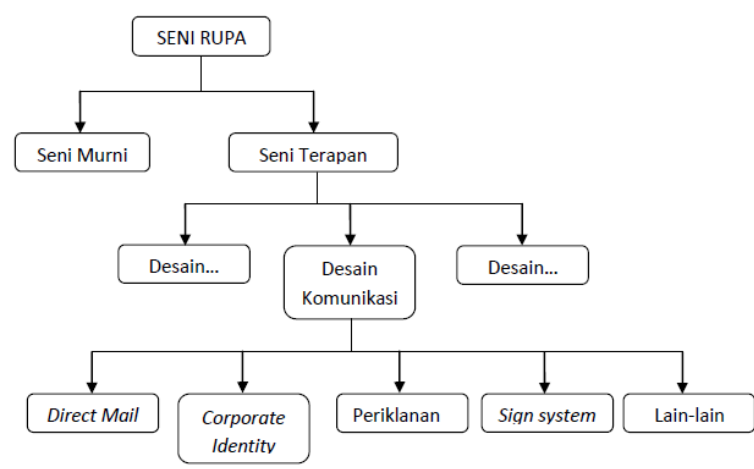

Gambar 6. Jaringan Hubungan antara Seni dan Deskomvis Periklanan

(Sanyoto, 2006)

\section{Sign System}

Sign system merupakan media yang digunakan untuk melakukan interaksi antar manusia di ruang publik. Pada penelitian kali ini ruang publik yang dimaksud adalah area wisata Kota Sawahlunto, dan dapat dipastikan banyak sekali pengunjung yang membutuhkan media sebagai petunjuk arah ketika berada di lingkungan tersebut.

Selain itu, menurut Piliang dalam Tinarbuko (2009) menyatakan bahwa suatu tanda bukan ilmu yang bersifat pasti, melainkan suatu hal yang dibangun oleh 
Gorga : Jurnal Seni Rupa

Volume 10 Nomor 02 Juli-Desember 2021

p-ISSN: 2301-5942 | e-ISSN: 2580-2380

pengetahuan yang lebih terbuka. Yang terpenting dalam sistem tanda pada desain komunikasi visual adalah fungsi dari tanda dalam menyampaikan pesan dari pengirim pesan kepada penerima, berdasarkan kode tertentu, yang dimediasi oleh media tertentu.

Sedangkan menurut Follins \& Hammer (1979), sign system justru merupakan bagian dari kesatuan lingkungan itu sendiri. Dalam pembuatan sign system terdapat elemen-elemen yang menjadi faktor kejelasan sign system antara lain: a). Elemen orientasi, diwujudkan dalam bentuk peta, denah setiap lantai, dan gedung yang merupakan suatu bentuk informasi grafis awal yang berfungsi untuk memberikan informasi dalam pengambilan keputusan oleh seseorang di dalam lingkungan yang belum dikenali. Alat-alat ini berfungsi utama untuk menyadari di mana ia berada, ke mana ia akan pergi, dan rute apa yang sebaiknya dipilih, b). Elemen informasi arahan, biasanya berupa sign yang dilengkapi dengan tanda-tanda panah atau panel-panel tombol. Elemen ini berfungsi bagi seseorang yang telah menemukan orientasinya, dan memberikan arahan melalui rute untuk menemukan lokasi yang ia tuju, c). Elemen identifikasi tujuan, elemen ini dapat berupa papan identitas dari nama gedung, identitas ruangan, dan nomor lantai. Penanda jenis ini dapat berada didalam maupun diluar ruangan karena berfungsi sebagai pembeda antara tempat yang satu dengan lainnya, d). Elemen situasi dan identitas obyek, elemen ini berfungsi menginformasikan suatu kondisi/situasi yang berlaku di dalam suatu lingkungan kepada orangorang yang sedang berada di dalamnya. Misalnya papan pemberitahuan/ arahan.

Jadi, dapat disimpulkan bahwa tanda yang ada dalam suatu media bertujuan menyampaikan pesan dari pengirim pesan kepada penerima tanpa mengabaikan elemen-elemen yang ada pada media itu sendiri.

\section{Usability}

Menurut Jeff Axup (2004), usability merupakan ukuran sebuah karakteristik yang mendeskripsikan seberapa efektifnya seorang pengguna dalam berinteraksi dengan suatu media. Yang mana usability juga merupakan sebuah ukuran seberapa mudahnya suatu media bisa dipelajari dan dipergunakan dengan cepat. Media disini diartikan seperti halnya tanda (sign). Sedangkan menurut Dumas (1999), usability digunakan untuk mengukur tingkat pengalaman penggunanya ketika berinteraksi dengan produk system, dimana usability mengacu kepada bagaimana pengguna bisa mempelajari dan menggunakan produk untuk memperoleh tujuannya dan seberapa puas mereka terhadap penggunaannya.
Jadi, dapat disimpulkan bahwa usability merupakan sebuah ukuran bagaimana pengguna dapat menggunakan produk untuk tujuannya dalam berinteraksi dengan suatu media.

\section{Efektivitas Melalui Direct Rating Method (DRM)}

Pada penelitian kali ini peneliti menggunakan Direct Rating Method (DRM) untuk menentukan efektivitas dari sign system yang terdapat di wisata Kota Sawahlunto. Metode ini digunakan untuk mengevaluasi kekuatan sebuah media yang berkaitan dengan kemampuan media itu untuk mendapatkan perhatian, mudah tidaknya media tersebut dibaca secara seksama, mudah tidaknya pesan media dipahami, kemampuan media untuk menggugah perasaan, dan kemampuan media untuk mempengaruhi perilaku pengunjung. Dalam metode ini semakin tinggi peringkat yang diperoleh berarti semakin tinggi kemungkinan media tersebut efektif, dan dalam penelitian ini yang menjadi media tersebut adalah sign system yang ada di area wisata Kota Sawahlunto.

Berikut ini merupakan aspek-aspek yang digunakan dalam model Direct Rating Method (DRM) (Durianto, 2003: a). Perhatian (attention), perhatian merupakan tingkatan awal seseorang menerima pesan. Ketika seseorang telah memberikan perhatian terhadap stimulus, maka ini pesan akan masuk ke dalam perhatian seseorang. Indikator dari perhatian adalah: Determinan pribadi, mengacu kepada karakteristik individu seseorang. Sub indikatornya adalah kebutuhan/motivasi, yang diukur apakah responden merasa membutuhkan informasi tentang wisata Kota Sawahlunto atau apakah seseorang tertarik untuk melihat sign system yang ada di wisata Kota Sawahlunto. Determinan stimulus, mengacu kepada stimulus yang menjadi perhatian bagi seseorang. Sub indikatornya adalah a) Ukuran, diukur apakah sign system sudah cukup terlihat ukurannya atau belum, b) Warna, diukur apakah warna-warnanya tajam dan serasi sehingga enak untuk dilihat dan tidak saling bertabrakan, c) Posisi : diukur apakah posisi peletakan sign system dapat dilihat dengan jelas oleh semua pengunjung wisata Kota Sawahlunto. b). Pemahaman (readthrougness), berkaitan dengan penafsiran dari suatu stimulus. Penafsiran suatu stimulus bergantung pada bagaimana sebuah stimulus diuraikan sesuai pengetahuan yang sudah ada. indikator yang mempengaruhi pemahaman adalah: Elaborasi stimulus, sub indikatornya adalah dilihat dari pencitraan untuk mengukur apakah pesan sign system mudah digambarkan secara jelas dalam ingatan. Determinan stimulus, sub indikatornya adalah linguistik, diukur apakah penggunaan kata-kata pada sign system mudah dimengerti. c). Efek kognitif, mengukur apakah sign system yang ada di wisata Kota Sawahlunto 
memberikan pengetahuan bagi pengunjung. Indikatornya adalah kesan terhadap sign system, diukur apakah pesan sign system dipaparkan dengan jelas dan mampu menampilkan informasi dengan menarik sehingga informasi dapat diterima dengan baik oleh pengunjung. d). Efek afektif, mengukur apakah sign system yang ada di wisata Kota Sawahlunto dapat menimbulkan perasaan atau emosi tertentu ketika pengunjung melihat sign system yang dibuat oleh pemerintah setempat. Indikatornya adalah pendirian (conviction), diukur apakah pesan sign system dapat meyakinkan pengunjung terhadap informasi/ petunjuk dari sign system tersebut. e). Efek sikap terhadap media (behavioral), sign system yang tersebar di wisata Kota Sawahlunto dapat membuat pengunjung melakukan tindakan sesuai dengan isi pesan sign system yang dilihatnya. Indikator dari sikap diukur dari apakah keberadaan sign system tersebut disukai atau tidak dalam memberi petunjuk/ informasi.

\section{METODE PENELITIAN}

Penelitian ini menggunakan pendekatan kuantitatif, yang bertujuan untuk menggambarkan/menjelaskan suatu masalah dengan mementingkan aspek keluasan data sehingga hasil data penelitian ini dianggap merepresentasikan seluruh populasi. Metode yang digunakan pada penelitian ini adalah metode survey dengan menggunakan kuesioner sebagai instrumen pengumpulan datanya dengan tujuan untuk memperoleh informasi tentang sejumlah responden yang dianggap mewakili populasi tersebut.

Pada penelitian ini, variabel efektivitas dari penggunaan (usability) sign system akan diukur menngunakan DRM, dengan 5 aspek yaitu aspek perhatian (attention), pemahaman, efek kognitif, efek afektif, dan efek behavioral. Sifat metodologi penelitian ini sendiri adalah asosiatif, karena bermaksud menjelaskan hubungan atau korelasi antarvariabel.

Terdapat dua jenis data dan tiga metode pengumpulan data yang digunakan dalam penelitian untuk mengetahui seberapa besar dampak (efektif) pengunaan sign system pada beberapa objek wisata di sekitar kawasan Kota Sawahlunto dengan menggunakan metode kuantitatif ini, yaitu untuk jenis data adalah sebagai berikut: a). Data primer, data primer merupakan data yang diperoleh dari sumber utama yaitu sampel dari populasi. Populasi adalah wilayah generalisasi yang terdiri dari obyek ataupun subyek yang memiliki kualitas dan karakteristik tertentu yang ditetapkan oleh peneliti untuk dipelajari dan ditarik kesimpulan (Sugiyono, 2009). Populasi pada penelitian kali ini adalah pengunjung yang datang atau wisatawan Kota Sawahlunto.

Sampel adalah bagian dari jumlah dan karakteristik yang dimiliki oleh populasi tersebut (Sugiyono, 2009). Sampel yang diambil haruslah yang representatif (mewakili) dari populasi yang ada, karena sampel merupakan perwakilan dari semua obyek dan karakteristik dari populasi. Pada penelitian kali ini, teknik sampling menggunakan non probability sampling, dimana tidak semua anggota populasi memiliki peluang yang sama untuk dipilih menjadi sampel dalam penelitian. Sedangkan teknik sampling non probabilitas yang digunakan adalah accidental sampling, yang merupakan teknik penentuan sampel berdasarkan kebetulan, yaitu siapa saja yang secara kebetulan bertemu dengan peneliti dapat digunakan sebagai sampel, bila dipandang orang yang kebetulan ditemui itu cocok sebagai sumber data. Adapun kriteria yang dimiliki oleh sampel adalah sebagai berikut: a) Merupakan pengunjung yang datang ke area wisata Kota Sawahlunto, b) Merupakan pengunjung yang mampu baca-tulis, c) Telah melihat sign system yang ada pada area wisata Kota Sawahlunto.

Dalam menghitung sampel yang dibutuhkan dari populasi dengan menggunakan rumus sebagai berikut (Zuriah, 2009):

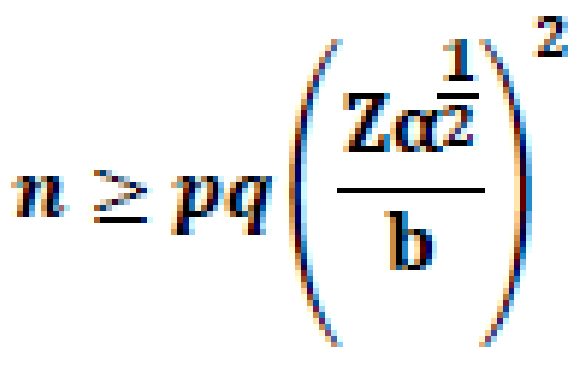

Jika jumlah populasi tidak dapat diperkirakan, maka variasi $\mathrm{p}$ dan $\mathrm{q}$ dapat diganti dengan harga maksimum, yakni $(0,05 \times 0,05=0,25)($ Zuriah, 2009). Dengan nilai $\mathrm{Z}^{1 / 2}$ (derajat koefisien), pada penelitian kali akan menggunakan tingkat kepercayaan 99\%, sehingga koefisiennya adalah 1,96 serta nilai $b$ atau persentase perkiraan kemungkinan membuat kekeliruan dalam membuat ukuran sampel. Pada penelitian kali ini tingkat eror data sebesar $10 \%(0,1)$. Setelah dilakukan kalkulasi diperoleh hasilnya adalah $n \geq 96,04$. Atau dengan kalimat lain, jumlah sample yang dicari adalah 96,04 orang pengunjung, yang dibulatkan menjadi 96 orang. b). Data sekunder, selain menggunakan kuesioner dalam pengumpulan data, peneliti juga menggunakan data sekunder, yaitu yang berasal dari pemrosesan hasil dari kusioner, jurnal serta beberapa sumber lainnya yang berasal dari Dinas Pariwiswata 


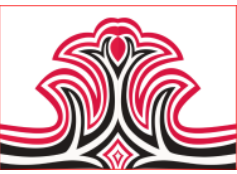

pemuda dan Olah Raga Kota Sawahlunto serta sumber-sumber lainnya yang dapat mendukung penelitian ini.

Sedangkan metode pengumpulan data adalah sebagai berikut: a). Kuesioner (angket), kuesioner yang dilakukan pada penelitian ini merupakan kuesioner tertutup, yang mana responden sudah diberikan beberapa alternatif jawaban oleh peneliti. Sehingga responden tinggal memilih jawaban yang sesuai dengan realitas yang dialaminya. Tingkat efektifitas dari usability sign system ini didasarkan pada hasil kuesioner yang diajukan kepada sample dari populasi yang ada, dengan mengajukan beberapa pertanyaan untuk mengetahui tingkat perhatian (attention), pemahaman, tingkat kognitif, tingkat afektif, dan tingkat behavioral. Penelitian kali ini menggunakan tipe skala Likert yang bertujuan untuk mengukur sikap seseorang tentang suatu obyek sikap. Setiap pernyataan dan pertanyaan dari kuesioner tersebut akan dihubungkan dengan jawaban yang berupa dukungan atau pernyataan sikap yang yang diungkapkan dengan kata-kata (Kriyantono, 2007). Dalam penelitian ini menggunakan 5 (lima) kategori jawaban, yaitu Sangat Baik (SB) dengan skor 5, Baik (B) dengan skor 4, Cukup (C) dengan skor 3, Tidak Baik (TB) dengan skor 2 dan Sangat Tidak Baik (STB) dengan skor 1. b). Observasi, merupakan kegiatan yang akan dilakukan oleh peneliti dalam mengamati secara langsung kegiatan yang ada di beberapa kawasan wisata Kota Sawahlunto. Dimana observasi juga sudah dilakukan sebelum penelitian berlangsung. c). Dokumentasi, bertujuan untuk memperoleh informasi yang mendukung analisis dan interpretasi data baik berupa dokumen dari arsip, buku dan website Dinas Pariwiswata Pemuda dan olahraga.

\section{HASIL DAN PEMBAHASAN}

1.Hasil

Sebelum kuesioner digunakan untuk pengumpulan data, maka terlebih dahulu diuji melalui validitas dan reabilitas menggunakan metode korelasi Product Moment dan Cronbach's Alpha. Setelah mendapatkan data dari hasil kuesioner, selanjutnya peneliti akan melakukan uji validitas dan reliabilitas. Berdasarkan hasil rekapitulasi, menunjukkan hasil yang valid, dimana nilai t-hitung dari koefisien validitas masingmasing butir pernyataan lebih besar dari nilai t-tabel 1,66 dengan $\alpha=5 \%$ dan $n=100-3=97$. Demikian halnya dengan hasil uji reliabilitas yang menunjukkan hasil yang reliabel dimana nilai koefisien reliabilitas yang didapat sebesar 0,917 lebih besar dari 0,70 (Ghozali, 2011). Dengan demikian instrumen
Gorga : Jurnal Seni Rupa

Volume 10 Nomor 02 Juli-Desember 2021 p-ISSN: 2301-5942 | e-ISSN: 2580-2380

penelitian memiliki validitas dan reliabilitas yang baik dan dapat digunakan untuk analisis selanjutnya.

\section{Pembahasan}

Data penelitian bersifat kuantitatif karena mengukur efektivitas dari penggunaan sign system di wisata Kota Sawahlunto, baik sebagai pemberi informasi tentang penjelasan bangunan cagar budaya, bentuk larangan/perintah, infromasi tempat wisata itu sendiri, informasi denah lingkungan ataupun petunjuk arah yang berguna untuk para pengunjung di wisata Kota Sawahlunto. Untuk mengevaluasi efektivitas dari penggunaan sign system tersebut di wisata Kota Sawahlunto, dilakukan dengan DRM melalui Analisis Tabulasi Sederhana dengan penghitungan rata-rata terbobot, sebagai berikut:

$$
\mathrm{P}=\frac{f i}{\sum f i} \times 100 \%
$$

Keterangan:

$\mathrm{P} \quad=$ Presentanse responden yang memilih kategori tertentu

fi $\quad=$ Jumlah responden yang memilih kategori tertentu

$\sum f i=$ Banyaknya jumlah responden

Setiap jawaban responden dari pertanyaan yang diberikan diberi bobot. Adapun cara menghitung skor rata-rata adalah sebagai berikut:

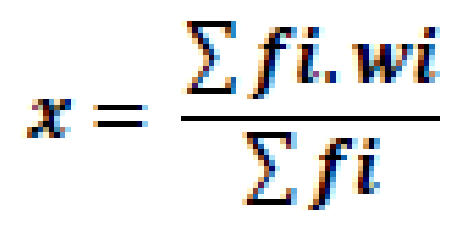

Keterangan:

$$
\begin{array}{ll}
x & =\text { Rata-rata berbobot } \\
f i & =\text { Frekuensi } \\
\text { wi } & =\text { Bobot }
\end{array}
$$

Setelah itu digunakan rentang skala penilaian untuk menentukan posisi tanggapan responden dengan menggunakan nilai skor setiap variabel. Skala peringkat terdiri dari kisaran 1 higga 5 yang menggambarkan posisi yang negatif ke posisi yang positif. Selanjutnya, dihitung rentang skala dengan rumus sebagai berikut: 


\section{$R s=\frac{R(b o b o t)}{M}$}

Keterangan:

$R$ (bobot) $=$ Bobot terbesar - bobot terkecil

$M \quad$ = Banyaknya kategori bobot

Karena skala Likert yang digunakan dalam penelitian kali ini adalah 1 s.d. 5, maka rentang skala penilaian yang didapat adalah:

\section{$R s=\frac{5-1}{5}=0,8$}

Sehingga posisi penilainnya menjadi sebagai berikut:

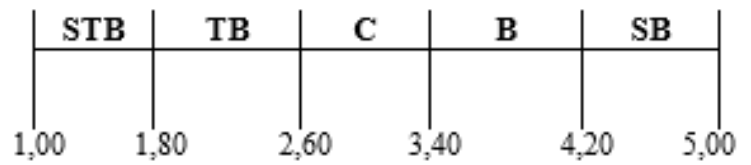

Gambar 7. Rentangan Penilaian

Keterangan:

$\mathrm{SB}=$ Sangat Baik, dengan rentang nilai $4,20-5,00$

$\mathrm{B}=$ Baik, dengan rentang nilai 3,40-4,19

$\mathrm{C}=$ Cukup, dengan rentang nilai 2,60 - 3,39

$\mathrm{TB}=$ Tidak Baik, dengan rentang nilai $1,80-2,59$

$\mathrm{STB}=$ Sangat Tidak Baik, dengan rentang nilai $1,00-1,79$

Hasil yang diperoleh kemudian dikonversikan ke table direct rating (tabel 1) untuk mengetahui apakah fungsi dari sign system tersebut dianggap tidak baik, kurang baik, cukup, baik, atau sangat baik dalam tingkat keefiktifannya dalam memberikan manfaat bagi pengunjung wisata Kota Sawahlunto.

Tabel 1. Direct Rating (Durianto, 2003)

\begin{tabular}{|c|c|}
\hline Rentang Skala & Kategori \\
\hline $0 \leq \mathrm{x}<20$ & Tidak Baik \\
\hline $20 \leq \mathrm{x}<40$ & Kurang Baik \\
\hline $40 \leq \mathrm{x}<60$ & Cukup \\
\hline $60 \leq \mathrm{x}<80$ & Baik \\
\hline $80 \leq \mathrm{x}<100$ & Sangat Baik \\
\hline
\end{tabular}

\section{KESIMPULAN DAN SARAN}

\section{Kesimpulan}

Bedasarkan analisis yang dilakukan peneliti terhadap usability (penggunaan) sign system tempat wisata Kota Sawahlunto sebagai Kota Tambang Berbudaya ini, dari hasil kuesioner yang dianalisis terhadap aspek-aspek
Gorga : Jurnal Seni Rupa

Volume 10 Nomor 02 Juli-Desember 2021

p-ISSN: 2301-5942 | e-ISSN: 2580-2380

yang yang digunakan dalam model Direct Rating Method (DRM), yaitu perhatian (attention), pemahaman (readthrougness), efek kognitif, efek afektif, dan efek sikap terhadap media (behavioral), yang melibatkan 97 responden dari 100 kuesioner yang disebarkan dapat disimpulkan bahwa efektivitas sign system yang berada di wilayah Kota Sawahlunto termasuk efektif dengan hasil pengunjung dapat mengidentifikasi objek wisata dengan baik dan cukup menyadari dimana lokasi ia berada dengan memperhatikan sign system yang ada, pengunjung juga dapat menemukan lokasi yang dituju serta mengetahui identitas situasi suatu objek dengan baik.

Hal ini dapat dilihat melalui nilai rata-rata setiap aspek yang berada pada skala penilaiannya yang sama, yaitu semuanya berada di rentang penilaian yang efektif dengan rata-rata sebagai berikut: a) aspek perhatian (attention) rata-ratanya 3.94, dengan nilai dimensi $(\mathrm{G})$ adalah $15,76, \mathrm{~b})$ aspek pemahaman rata-ratanya 3.65 , dengan nilai dimensi $(\mathrm{G})$ adalah 14,60 , c) aspek efek kognitif rata-ratanya 3.85 , dengan nilai dimensi $(G)$ adalah 15,40 , d) aspek efek afektif rata-ratanya 3.90, dengan nilai dimensi (G) adalah 15,60 dan e) aspek efek behavioral rata-ratanya 3.90, dengan nilai dimensi (G) adalah 15,60. Pada akhirnya, nilai pada skala di tabel direct rating memiliki nilai total rata-rata semua aspek yaitu sebesar 76.96 (Gambar 6) sehingga melalui tabel Direct Rating Method, sign system termasuk dalam kategori baik sebagai media komunikasi visual yang berada di ruang publik, yaitu berada di wisata Kota Sawahlunto.

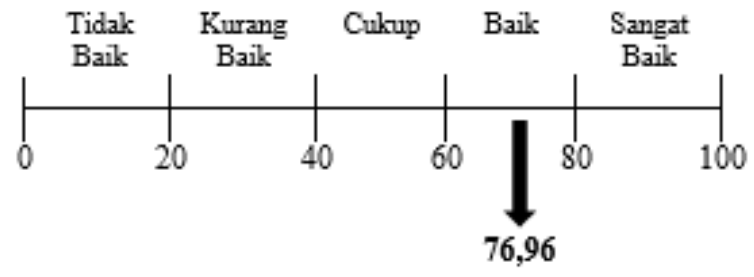

Gambar 8. Garis Dimensi (G)

\section{Saran}

Efektivitas dari sign system di wisata Kota Sawahlunto sudah termasuk dalam kategori baik, tapi masih memungkinkan untuk dikembangkan dan ditingkatkan sehingga menjadi lebih baik lagi. Hal ini dapat dilihat dari kesimpulan yang telah diambil sebelumnya, bahwa nilai pada aspek pemahaman (readthrougness), masih lebih rendah dibandingkan nilai pada aspek lainnya.

Aspek pemahaman (readthrougness) berkaitan dengan penafsiran dari suatu stimulus. Penafsiran suatu stimulus bergantung pada bagaimana sebuah stimulus 


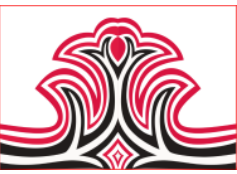

diuraikan sesuai pengetahuan yang sudah ada. Dengan salah satu sub indikator yang mempengaruhinya linguistik, yang diukur melalui "apakah penggunaan kata-kata pada sign system mudah dimengerti". Adapun beberapa saran dari pengunjung/ peneliti untuk menginkatan aspek tersebut antara lain: a). Rangkuman cerita sejarah/ riwayat/ asal usul atau suatu sign system yang mengandung informasi terkait area wisata tersebut tersampaikan dengan singkat, jelas dan atraktif. b). Mendukung upaya pengembangan tempat wisata Kota Sawahlunto sebagai Kota Tambang Berbudaya ini sebaiknya sign system yang ada disekitar tempat wisata tersebut diseragamkan sehingga terlihat selaras sebagai salah satu city branding Kota Sawahlunto sebagai Kota Tambang Berbudaya.

\section{DAFTAR RUJUKAN}

Behance. (2020). Sign System Berupa Petunjuk. https://www.behance.net/gallery/8364147/

Redesign-Signage-System-for-TamanMargasatwa-Ragunan (diakses tanggal 29 Februari 2020).

Dumas, Joseph S dan Redish, Janice C. (1999). A Practical Guide to Usability Testing. USA: Intellect.

Durianto, Darmadi dkk. (2003). Invasi Pasar dengan Iklan yang Efektif (Strategi, Program, dan teknik Pengukuran). Jakarta: PT Gramedia Pustaka Utama.

Evrinaldi. (2020). Kota Tua Sawahlunto Diajukan Menjadi Warisan Dunia.

www.sawahluntotourism.com (diakses tanggal 29 Februari 2020).

Follins, John \& Hammer, Dave. (1979). Architectural Signing \& Graphics. New York: Whitney Library of Design.

Ghozali, Imam. (2011). Aplikasi Analisis Multivariate Dengan Program IBM SPSS 19. Semarang: Badan Penerbit Universitas Diponegoro.

Jeff, Axup. (2004). Usability Professionals Association, About Usability. Australia: The University of Queensland.

Kriyantono, Rachmat. (2007). Teknik Praktis Riset Komunikasi. Jakarta: Kencana.

Kusrianto, Adi. (2009). Pengantar Desain Komunikasi Visual. Jakarta: Penerbit ANDI.

Narny, Yenny. (2015). Sawahlunto Perjalanan ke Masa Lalu. Sawahlunto: CV Celyfa.

Portaldekave. (2021). Sign System Berupa Larangan. https://www.portaldekave.com/artikel/peng ertian-serta-pemahaman-sign-systemmenurut-para-ahli (diakses tanggal 3 Maret 2021).

Rama, Kertamukti. (2012). Komunikasi Visual dalam
Gorga : Jurnal Seni Rupa

Volume 10 Nomor 02 Juli-Desember 2021

p-ISSN: 2301-5942 | e-ISSN: 2580-2380

Periklanan. Yogyakarta: Penerbit Galuh Yogyakarta.

Sugiyono. (2009). Metode Penelitian Kuantitatif, Kualitatif dan $R \& D$. Bandung: Alfabeta.

Sunyoto, Sadjiman Ebdi. (2006). Metode Perancangan Komunikasi Visual. Yogyakarta: Dimensi Press.

Tinarbuko, Sumbo. (2009). Semiotika Komunikasi Visual. Yogyakarta: Widyatama Rendra.

Yulnita, Novika. (2020). "Sign System". Hasil Dokumentasi Pribadi: 20 Agustus 2020, Kota Sawahlunto.

Zuriah, Nuzul. (2009). Metodologi Penelitian Sosial Pendidikan Teori-Aplikasi. Jakarta: PT Bumi Aksara. 